\title{
Non-damaging flow below the Mietków reservoir on the Bystrzyca river
}

\author{
Ryszard Kosierb \\ Institute of Meteorology and Water Management, National Research Institute, Wroctaw Branch, Parkowa Street 30, \\ 51-616 Wrocław, e-mail: ryszard.kosierb@imgw.pl
}

\begin{abstract}
Non-damaging flow below storage reservoirs is one of the key factors which affect proper water management, especially the protection of valleys against flooding. Following analysis of river flow capacities below reservoirs it should be noted that, over the years, these capacities are subject to significant limitations. This is usually caused by inappropriate floodplain management. Buildings are often built closer to the river channels, which in consequence causes flooding of the buildings at low flood discharges. Repeated inundations and thus increasing losses oblige the local authorities to maintain low outflows from reservoirs in the first phase of the freshet, which leads to a rapid fulfillment of flood reserves of the reservoirs. Then, the culmination of flood wave often takes place when the reservoirs are filled and consequently high discharges from the reservoirs must be realized. This causes flooding of the areas and buildings below the storage reservoirs.

This situation could have been avoided if the riverbeds and floodplains had been adjusted to pass non-damaging flow and adopted it as the basis for the water management of a given reservoir. A significant improvement in reduced reservoir capacities will occur if the values of non-damaging flow below the reservoirs are increased and the losses caused by flood flow are significantly reduced by appropriate spatial development of the areas below the storage reservoirs. The current non-damaging flow below the Mietków reservoir is a striking example of the issue. Three farms located within the floodplain of the Bystrzyca river have an adverse impact on water management of the reservoir when floods take place.
\end{abstract}

Key words: reservoirs, non-damaging flow, flood

Submitted 15 April 2013, received 27 May 2013, accepted 13 November 2013

\section{Introduction}

Non-damaging flow below storage reservoirs is one of the key factors which affect proper water management, especially the protection of valleys against flooding. Following analysis of river flow capacities below reservoirs it should be noted that, over the years, these capacities are subject to significant limitations. This is usually caused by inappropriate floodplain management. Buildings are often built closer to the river channels, which in consequence causes flooding of the buildings at low flood discharges. Repeated inundations and thus increasing losses oblige the local authorities to maintain low outflows from reservoirs in the first phase of the freshet, which leads to a rapid fulfillment of flood reserves of the reservoirs. Then, the culmination of flood wave often takes place when the reservoirs are filled and consequently high discharges from the reservoirs must be realized. This causes flooding of the areas and buildings below the storage reservoirs.

This situation could have been avoided if the riverbeds and floodplains had been adjusted to pass non-damaging flow and adopted it as the basis for the water management of a given reservoir. A significant improvement in reduced reservoir capacities will occur if the values of non-damaging flow below the reservoirs are increased and the losses caused by flood flow are significantly reduced by appropriate spatial development of the areas below the storage reservoirs.
The current non-damaging flow below the Mietków reservoir is a striking example of the issue. Three farms located within the floodplain of the Bystrzyca river have an adverse impact on water management of the reservoir when floods take place (Kosierb 2007).

\section{Characteristic of chosen reservoirs in the catch- ment of the Bystrzyca river}

In the catchment of the Bystrzyca river, a left-side tributary of the Odra river, three water reservoirs can be found, namely: the Mietków reservoir, the Dobromierz reservoir, and the Lubachów reservoir, Fig. 1.

\subsection{The Mietków reservoir}

The Mietków reservoir, situated on the Bystrzyca river, is the largest artificial reservoir in the Lower Silesia region, with an area of 950 hectares of floodplain, about $4 \mathrm{~km}$ long, with a width of $2.5 \mathrm{~km}$ with a maximum depth of about $11 \mathrm{~m}$ (Fig. 1). The water management on the Mietków reservoir has a major influence on the formation of discharges at the Jarnołtów water-gauge section. The main task of this reservoir is to collect water for the alimentation of the Odra river, and in consequence to increase the transit depths for shipping on the free flowing Odra river. However, the main task of the reservoir during floods on the Bystrzyca river is to hold water so as to protect the val- 


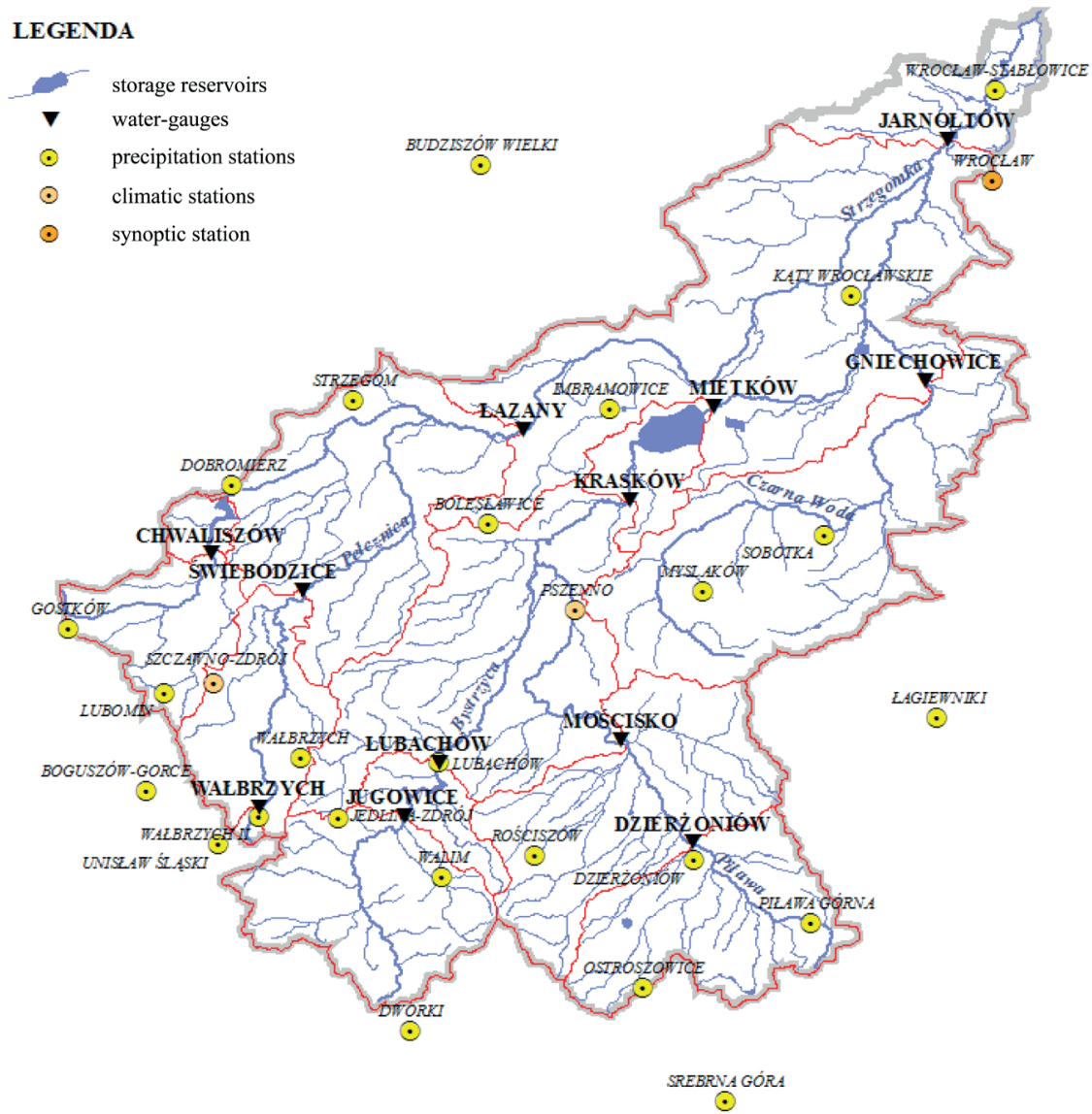

Figure 1. River system and localization of retention reservoirs in the catchment of the Bystrzyca river

ley of the river against flooding. In addition, the reservoir has a beneficial effect on the water quality in the sector between the reservoir and the mouth of the Strzegomka river. It is also of note that the Polish Angling Association is in charge of fish farming in the reservoir.

The parameters of the Mietków reservoir are presented in Tab. 1.

Table 1. The characteristic parameters of the Mietków Reservoir

\begin{tabular}{|l|r|c|}
\hline Specification & value & unit \\
\hline total capacity & 83.78 & $\mathrm{mln} \mathrm{m}^{3}$ \\
\hline dead storage capacity & 3.71 & $\mathrm{mln} \mathrm{m}^{3}$ \\
\hline useful reservoir capacity & 53.09 & $\mathrm{mln} \mathrm{m}^{3}$ \\
\hline total flood reservoir capacity & 26.98 & $\mathrm{mln} \mathrm{m}^{3}$ \\
\hline
\end{tabular}

Source: up-to-date data of Regional Water Management Board, Wrocław

Characteristic outflows from the Mietków reservoir:

- non-damaging outflow $-40 \mathrm{~m}^{3} / \mathrm{s}$;

- flood outflow - $120 \mathrm{~m}^{3} / \mathrm{s}$;

- outflow for alimentation of the Odra Waterway $15 \mathrm{~m}^{3} / \mathrm{s}$, exceptionally maximum $25 \mathrm{~m}^{3} / \mathrm{s}$.

The non-damaging flow below the Mietków reservoir is equal to $40 \mathrm{~m}^{3} / \mathrm{s}$. It does not lead to any damage in the sector of the Bystrzyca river between the reservoir and the village of Jarnołtów. Above the Jarnołtów water-gauge station, located in the town of Samotwór, the waters of the
Bystrzyca river and the Strzegomka river connect. Thus, the discharge measured at the Jarnołtów water-gauge station covers not only the outflow from the Mietków reservoir but also the outflow from the Bystrzyca river below the reservoir and the outflow from the whole catchment of the Strzegomka river.

\subsection{The Dobromierz reservoir}

The Dobromierz reservoir, with a total capacity of 11.75 million $\mathrm{m}^{3}$ (Tab. 3), is located on the Strzegomka river at the $59.0 \mathrm{~km}$ mark (Fig. 1). In terms of administrative division, the reservoir and its topographic basin are located in the province of Lower Silesia, on the border of the counties Wałbrzych and Świdnica, within the municipalities of Stare Bogaczowice and Dobromierz.

The main objectives of the Dobromierz reservoir are as follows:

- to supply the cities of Świebodzice and Dobromierz with municipal water

- to protect the areas located below the reservoir against flooding by maintaining the flood reserve in the reservoir,

- to ensure the ecological discharges in the Strzegomka river below the dam.

The total capacity of the Dobromierz reservoir is equal to 11.35 million $\mathrm{m}^{3}$, while the flood reserve, between 
the maximum and normal level of damming is equal to 1.35 million $\mathrm{m}^{3}$. The flood reserve is too small to substantially reduce the discharges on the Strzegomka river higher than $64 \mathrm{~m}^{3} / \mathrm{s}$.

According to the water-legal permit, the following water discharges can be realized:

- $0.15 \mathrm{~m}^{3} / \mathrm{s}-$ minimum outflow,

- $15 \mathrm{~m}^{3} / \mathrm{s}$ - non-damaging outflow,

- $25 \mathrm{~m}^{3} / \mathrm{s}$ - flood outflow.

In order to conduct proper management of the water reservoir, the following measurements are realized:

- the upper water-gauge levels on the outflow tower,

- the lower water-gauge levels on the outflow channel,

- the water-gauge station Chwaliszów,

- the precipitation stations in Lubomin and Gostków.

\section{Water management on the reservoirs during the flood}

\subsection{The Mietków reservoir}

During a flood, the Coordination and Information Center of Regional Water Management Board (RZGW) in Wrocław takes total responsibility of the water management on the reservoir. Decisions on the volume of discharges from the reservoir are taken by the Director of RZGW in Wrocław. These decisions are agreed with the Provincial Crisis Management Center and the Municipal Emergency Management Center in Wrocław.

The non-damaging flow from the reservoir has been established by a water-legal permit as equal to $40 \mathrm{~m}^{3} / \mathrm{s}$.

The flood outflow, which causes losses in agriculture, is equal to $120 \mathrm{~m}^{3} / \mathrm{s}$.

During a flood, hydrological observations are essential for the water management on the reservoir. An important task of the observation is to provide information about current and forecast discharges on the Bystrzyca and Strzegomka rivers. The forecast of the discharges is developed on the basis of the following information:

1. observed water-gauge stages on the reservoir, the actual and forecast discharges from the Dobromierz and Lubachów reservoirs, rating curves, relationships between neighbouring water-gauges,

2. observed precipitation and groundwater levels in the basin,

3. forecast precipitation,

4. surface coefficients.
Forecasts of the inflows into the water reservoirs should be transmitted to the Information and Coordination Center of RZGW in Wroclaw in the form of hydrographs. They are essential for the proper running of steered water management during a flood. In cases of a lack of forecasts (i.e. if inflow hydrographs have only the volumes of wave and the time of flooding duration) the so-called predicted management is applied (Lambor 1962). In cases of an absence of forecast of inflow into the reservoir, rigid or semirigid water management should be used. Nevertheless, the type of water management should be followed by an analysis of the work of the reservoir during historical high waters occurring in the catchment of the Bystrzyca river.

According to the Water-management instructions - the Mietków reservoir on the Bystrzyca river developed by Hydroprojekt Wrocław (Hydroprojekt Wrocław 1998), the following principles should be applied during flooding:

1. the outflow from the reservoir can be increased to the value of $40 \mathrm{~m}^{3} / \mathrm{s}$ after receiving forecasts which project an increase in the inflow to the reservoir exceeding $40 \mathrm{~m}^{3} / \mathrm{s}$, when normal damming is currently achieved;

2. the discharge can be increased to $120 \mathrm{~m}^{3} / \mathrm{s}$ provided that the forecasts of the increase in the inflow to the reservoir exceeding the value are obtained

3. emptying the constant flood reserve should be carried out after reducing the inflow into the reservoir below $40 \mathrm{~m}^{3} / \mathrm{s}$, while it is acceptable to maintain outflow at $40 \mathrm{~m}^{3} / \mathrm{s}$ until the constant flood reserve is emptied.

The above-mentioned principles are not obligatory and in every instance the decision-making process requires a case by case evaluation of the situation.

\subsection{The Dobromierz reservoir}

In accordance with the Exploitation and water-management instructions - the Dobromierz reservoir on the Strzegomka river developed in 2002 by Hydroprojekt Wrocław (Hydroprojekt Wrocław 2012), the water management during a flood is conducted by the head of the reservoir, in consultation with the Legnica Branch of RZGW Wrocław and the District Center for Crisis Management in Świdnica. However, the IMGW Wrocław Branch transmits the short and long-term weather forecasts to the Coordination Information Center at RZGW Wrocław.

Table 2. The characteristics of water-gauges

\begin{tabular}{|l|l|c|c|c|}
\hline Water-gauge & $\mathrm{km}$, localization & $\begin{array}{c}\text { Area of the } \\
\text { basin }\end{array}$ & $\begin{array}{c}\text { Coordinate „0" } \\
\text { of the water-gauge }\end{array}$ & Date of construction \\
\hline Krasków & $\begin{array}{l}50.7 \mathrm{~km} \\
\text { (above the Mietków reservoir) }\end{array}$ & 683 & 176.28 & 1936 \\
\hline Mietków & $\begin{array}{l}40.8 \mathrm{~km} \\
\text { (below the Mietków reservoir) }\end{array}$ & 722 & 152.65 & 1986 \\
\hline Jarnołtów & $\begin{array}{l}12.8 \mathrm{~km} \\
\text { (below the Mietków reservoir) }\end{array}$ & 1710 & 116.25 & 1953 \\
\hline
\end{tabular}


Table 3. The discharges at selected gauges, with a given probability of exceedance and corresponding coordinates of water tables, according to IMGW Wrocław

\begin{tabular}{|c|c|c|c|c|c|c|c|}
\hline River & Water-gauge & $\begin{array}{c}\mathrm{Q}_{10 \%} \\
\left(\mathrm{~m}^{3} / \mathrm{s}\right)\end{array}$ & $\begin{array}{l}\mathrm{H}_{10 \%} \\
(\mathrm{~cm})\end{array}$ & $\begin{array}{c}\mathrm{Q}_{1 \%} \\
\left(\mathrm{~m}^{3} / \mathrm{s}\right)\end{array}$ & $\begin{array}{l}\mathrm{H}_{1 \%} \\
(\mathrm{~cm})\end{array}$ & $\begin{array}{l}\mathrm{Q}_{0,5 \%} \\
\left(\mathrm{~m}^{3} / \mathrm{s}\right)\end{array}$ & $\begin{array}{l}\mathrm{H}_{0,5 \%} \\
(\mathrm{~cm})\end{array}$ \\
\hline \multirow{5}{*}{ Bystrzyca } & Jugowice & 80.5 & 198 & 174 & 295 & 203 & 313 \\
\hline & Lubachów & 47.6 & 277 & 104 & 330 & 121 & \\
\hline & Krasków & 133 & 353 & 262 & 415 & 301 & 435 \\
\hline & Mietków & 48.3 & 330 & 140 & 440 & 185 & 490 \\
\hline & Jarnołtów & 151 & 344 & 380 & 448 & 475 & 486 \\
\hline \multirow{2}{*}{ Piława } & Dzierżoniów & 40.4 & 353 & 87.2 & 461 & 102 & 479 \\
\hline & Mościsko & 53.0 & 330 & 98.7 & 390 & 112 & \\
\hline \multirow{2}{*}{ Strzegomka } & Chwaliszów & 41.0 & & 89.1 & & 105 & \\
\hline & Łażany & 67.3 & 391 & 142 & & 166 & \\
\hline Pełcznica & Świebodzice & 28.9 & 224 & 62.7 & 305 & 75.7 & 325 \\
\hline Czarna-Woda & Gniechowice & 28.2 & 214 & 56.7 & & 65.4 & \\
\hline
\end{tabular}

\section{Basic hydrological data}

For the water management carried out on the reservoir, information about the conditions and controlled flows at water-gauges along the Bystrzyca river (i.e. at Krasków, Mietków, Jarnołtów) is crucial. The flood protection on the Bystrzyca river includes the following water-gauges, namely: Krasków and Jarnołtów. The characteristics of the water-gauges are presented below (Tab. 2).

The Mietków water-gauge is located immediately below the Mietków Reservoir for which the discharge amounts to $\mathrm{Q}_{10 \%}=48.3 \mathrm{~m}^{3} / \mathrm{s}$, the discharge $\mathrm{Q}_{1 \%}=$ $40 \mathrm{~m}^{3} / \mathrm{s}$, while the discharge $\mathrm{Q}_{0,5 \%}=185 \mathrm{~m}^{3} / \mathrm{s}$ (according to IMGW Wrocław, Tab. 3).

The waters of the Bystrzyca river in the sector between the Mietków reservoir and the Jarnołtów water-gauge station are supplied mainly by two side tributaries - the Czarna Woda and Strzegomka.

The Czarna Woda river is controlled by the watergauge station Gniechowice, for which the discharge is $\mathrm{Q}_{10 \%}=28.2 \mathrm{~m}^{3} / \mathrm{s}$, the discharge $\mathrm{Q}_{1 \%}=56.7 \mathrm{~m}^{3} / \mathrm{s}$, while the discharge $\mathrm{Q}_{0,5 \%}=65.4 \mathrm{~m}^{3} / \mathrm{s}$

The discharges on Jarnołtów water-gauge station depend not only on the water management in the Mietków Reservoir, but also largely on discharges of the Strzegomka and Czarna Woda rivers.

The upper part of the catchment of the Strzegomka river is controlled by the Dobromierz Reservoir, from which outflows are essential for the flood protection of the valley below the reservoir.

\section{Scenarios of threats for the Bystrzyca valley}

During flooding, the District Crisis Management Centre in Świdnica should be informed about outflows from the reservoir higher than $15 \mathrm{~m}^{3} / \mathrm{s}$. Flood management of the reservoir covers the period when the water level in the reservoir is equal to or higher than the normal level of damming and the tributary to the reservoir exceeds the non-damaging outflow $\mathrm{Q}_{\mathrm{doz}}=15 \mathrm{~m}^{3} / \mathrm{s}$. It continues until the total flood reserve is restored, while exceeding the maximum level of damming can occur only in exceptional circumstances. Such a situation can occur when the flood wave is higher than the reliable wave $Q=64 \mathrm{~m}^{3} / \mathrm{s}$. However, after reaching the level of 300.1 meters above sea level, bottom vents must be fully open.

Below the Dobromierz reservoir a significant tributary, namely the Pełcznica river, flows into the Strzegomka river (Fig. 1). The waters of the Strzegomka and Pełcznica rivers are controlled by the Lazany water-gauge, located on the Strzegomka River. The discharge for the watergauge is $\mathrm{Q}_{10 \%}=67.3 \mathrm{~m}^{3} / \mathrm{s}$, the discharge $\mathrm{Q}_{1 \%}=142 \mathrm{~m}^{3} / \mathrm{s}$, while the discharge $\mathrm{Q}_{0,5 \%}=166 \mathrm{~m}^{3} / \mathrm{s} /$

The waters of the Bystrzyca and Strzegomka rivers join in the town of Samotwór (Fig. 1) and are controlled by the Jarnołtów water-gauge station located below this confluence. The water levels on the water-gauge during the flow of flood waters are the basis for the implementation of appropriate scenarios in the region of the city of Wrocław by institutions responsible for flood protection.

In order to protect the life and property of the inhabitants of the districts of Wrocław located in the Bystrzyca valley, the City Crisis Management Center in Wrocław has developed six scenarios of threats relating to specified levels and flows of the Bystrzyca on the Jarnołotów watergauge (IMGW Wrocław 2003).

\section{Scenario I:}

When the level at the Jarnołtów water-gauge is $\mathrm{H}=$ $285-320 \mathrm{~cm}$ and discharge $\mathrm{Q}=57-110 \mathrm{~m}^{3} / \mathrm{s}$, the valley of the river between the town of Samotwór and Jarnołtów is flooded. At the level of about $300 \mathrm{~cm}$ on the water-gauge, water reaches buildings on Gałowska Street.

\section{Scenario II:}

When the level at the Jarnołtów water-gauge is $\mathrm{H}=$ $320-360 \mathrm{~cm}$ and the discharge $110-178 \mathrm{~m}^{3} / \mathrm{s}$, the river valley in the section between the city limits and railroad bridge 


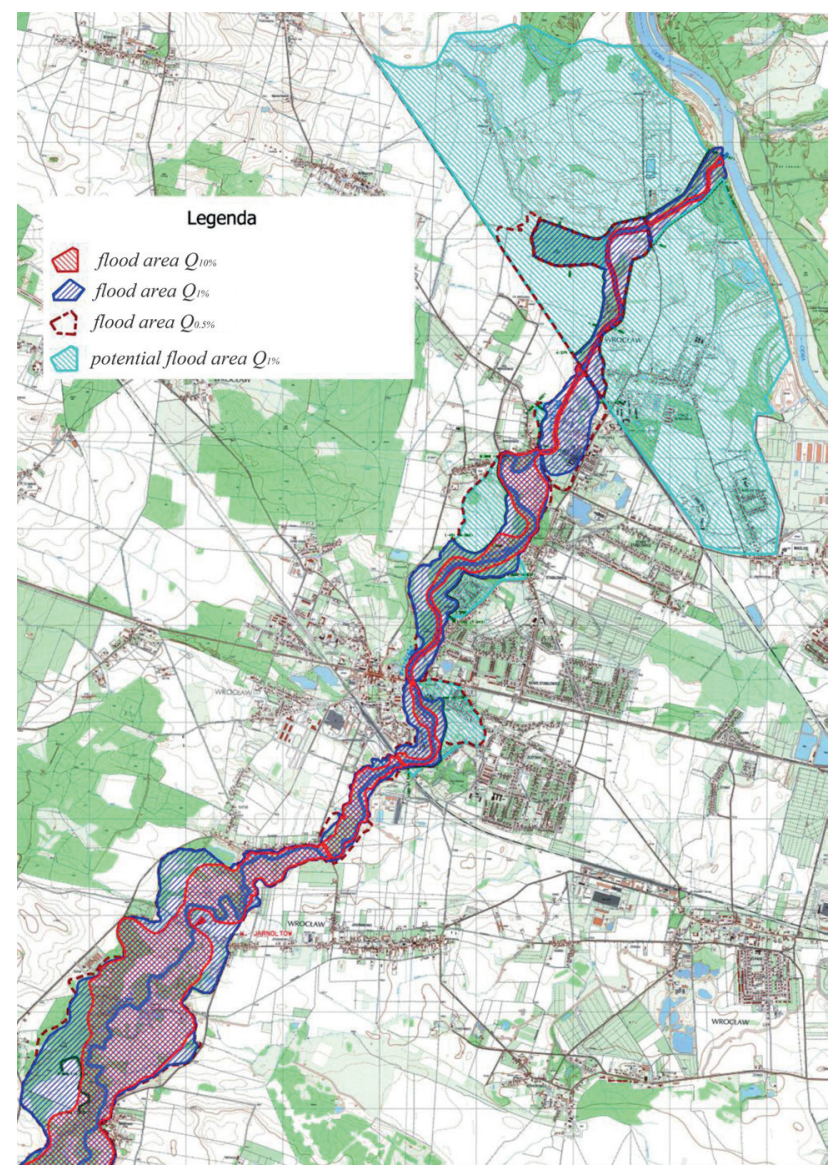

Figure 2. The scope of the flooding at a discharge of $\mathrm{Q}_{10 \%}$, $\mathrm{Q}_{1 \%}, \mathrm{Q}_{0,5 \%}$ in the areas of the municipality of Wrocław

in Leśnica is flooded. Below Leśnica, low-lying areas and flood land are flooded, while in the region of Promenada Street and Skoczylas Street, gardens and courtyards are flooded. Fig. 2 (IMGW Wrocław 2003) presents the extent of the flooding, marked with red at a discharge of Q10\% $=$ $151 \mathrm{~m}^{3} / \mathrm{s}$, which corresponds to the level at the Jarnołtów water-gauge $\mathrm{H}=344 \mathrm{~cm}$. Buildings on Gałowska Street are then flooded to a depth of $60 \mathrm{~cm}$.

\section{Scenario III:}

When the level at the Jarnoltów water-gauge is $\mathrm{H}=360-385 \mathrm{~cm}$ and the discharge $\mathrm{Q}=178-235 \mathrm{~m}^{3} / \mathrm{s}$, buildings on Gałowska Street are flooded to a depth of about 1 meter. In Leśnica, houses at 47 and 49 Skoczylas Street are flooded, as well as some on Promenada Street (No. 38 and part of No. 26 and No. 24). Furthermore, parts of domestic gardens with outhouses are also flooded. A mill at 1 Średzka Street and the bridge in Jarnołotów are also under threat.

\section{Scenario IV:}

When the level at the Jarnoltów water-gauge is $\mathrm{H}=385-440 \mathrm{~cm}$ and discharge $\mathrm{Q}=235-364 \mathrm{~m}^{3} / \mathrm{s}$, buildings on Gałowska Street will be flooded to a depth of about $1.5 \mathrm{~m}$. Buildings on Jarnołtowska Street will also be flooded. A bridge and old mill building will be at threat.
In Leśnica District, not only buildings at 38, 37, 36, 34, 32, 30, 29, 27 26, 24, 22, 20, 18 Promenada Street will be flooded, but also buildings at 47 and 49 Skoczylas Street. In Ratyń District the water will reach Gromadzka Street. In cases of broken flood embankments, there is a threat of flooding to the wastewater treatment plant in Janówek and the following housing developments: Nowa Karczma, Pracze Odrzańskie, Marszowice, Stabłowice and Złotnik.

Scenario V:

When the level at the Jarnołatów watergauge is $\mathrm{H}=440-465 \mathrm{~cm}$ and the discharge $\mathrm{Q}=364-420 \mathrm{~m}^{3} / \mathrm{s}$, buildings on Gałowska Street will be flooded to the depth of $1,75 \mathrm{~m}$. Buildings on Jarnołotowska Street will be also flooded. The bridge and the building of the old mill will be at threat. Buildings at 38, 37, 36, 32, 29, 24, 22, 26, 24, 22, 20, 18 Promenada Street will be flooded and buildings on the same street at Nos. 33, 25, 23 would be slightly flooded, as well as buildings at 47,49,52 and 54 Skoczylas Street.

The water will reach the level of the crown of the embankment Marszowice I and Marszowice II. Buildings on Marszowicka and Wilkszyńska Street will be in danger. The water may overflow through the embankment Janówek-Marszowice, threatening the wastewater treatment plant. Fig. 2 presents the scope of flooding at the 
discharge of $\mathrm{Q}_{1 \%}=380 \mathrm{~m}^{3} / \mathrm{s}$, marked in blue. It correlates with the level at the Jarnołtów water-gauge $\mathrm{H}=448 \mathrm{~cm}$.

\section{Scenario VI:}

When the level at the Jarnołtów water-gauge is $\mathrm{H}=465-520 \mathrm{~cm}$ and the discharge $\mathrm{Q}=420-554 \mathrm{~m}^{3} / \mathrm{s}$, the water will come to the crown of the embankments protecting the following housing developments: Stabłowice, Złotniki, Pracze, and partly to the crown of JanówekMarszowice embankment $(\mathrm{km} 0+00 \div 2+570)$. However, it will overflow through the section of Janówek-Marszowice embankment $(\mathrm{km} 2+570 \div 3+100)$. The housing developments of Arnołotów, Leśnica and Marszowice will be partly flooded. The following housing developments will be in danger - Pracze, Stabłowice and Złotniki. Fig. 2 presents the scope of flooding at the discharge of $Q_{0,5 \%}=475 \mathrm{~m}^{3} / \mathrm{s}$, marked in red. This corresponds to the level at Jarnołotów water-gauge $\mathrm{H}=486 \mathrm{~cm}$ (IMGW Wrocław 2003).

\section{Conclusions}

1. Having analyzed the values of discharges with a given probability of exceedance, provided by IMGW Wrocław Branch (Tab. 3), it should be concluded that the Bystrzyca river is crucial for the volume of discharges at the Jarnołtów water-gauge. The volume of discharges on the river itself mainly depends on the water management on the Mietków reservoir. Thanks to a significant flood reserve created after the flood of 1997 on the reservoir, flood waves may be extensively reduced. Nevertheless, this depends on an accurate forecast of the volume of wave flowing to the reservoir and also the absence of any obstacles occurring while carrying out the permitted discharge to the amount of at least $80 \mathrm{~m}^{3} / \mathrm{s}$. However, the elimination of buildings in the region of Gałowska Street below the Mietków reservoir would be required.

2. The Dobromierz reservoir has an insignificant capability of reducing considerable flood waves in Strzegomka and Bystrzyca due to its small flood capacity.
3. All flood waves which have occurred in the catchment of the Bystrzyca river should be analyzed and, on the basis of the analyses, scenarios for water management on the Mietków reservoir should be developed. They should not only allow for maximum wave reduction on the Bystrzyca river, but should also ensure no overlapping of a culmination of flood waves of the Bystrzyca and Strzegomka rivers.

\section{Bibliography}

Kondracki J., 1994, Geografia Polski. Mezoregiony fizycznogeograficzne, PWN, Warszawa, $340 \mathrm{pp}$

Kosierb R., 2007, Rola zbiornika retencyjnego Mietków podczas transformacji fali powodziowej na rzece Bystrzycy w sierpniu 2006, Polska Akademia Nauk, Komisja Technicznej Infrastruktury Wsi, Kraków

Lambor J., 1962, Gospodarka wodna na zbiornikach retencyjnych, Warszawa, $257 \mathrm{pp}$

Charakterystyka Istniejących Realizowanych i Planowanych Obiektów Hydrotechnicznych, in: Identyfikacja Głównych Problemów Użytkowania Zasobów Wodnych Odry na Obszarze Działania RZGW we Wrocławiu, Instytut Meteorologii i Gospodarki Wodnej Oddział Wrocław, Wrocław (unpublished)

Instrukcja eksploatacji i gospodarki wodnej - zbiornik Dobromierz na rzece Strzegomce, 2002, Hydroprojekt Wrocław, (unpublished)

Instrukcja gospodarki wodnej - zbiornik wodny Mietków na rzece Bystrzycy, 1998, Hydroprojekt Wrocław, (unpublished)

Studium ochrony przed powodzią zlewni rzeki Bystrzycy, 2003, Instytut Meteorologii i Gospodarki Wodnej Oddział Wrocław, Wrocław, (unpublished)

Scenariusze zagrożeń dla określonych stanów i przepływów w Bystrzycy w przekroju wodowskazowym Jarnołtów, 2010, Miejskie Centrum Zarządzania Kryzysowego we Wrocławiu, Wrocław, (unpublished) 